\title{
COMUNICAÇÃO ORGANIZACIONAL E MIDIATIZAÇÃO SOCIAL: UMA REFLEXÃO CONTEMPORÂNEA
}

\author{
ORGANIZATIONAL COMMUNICATION AND SOCIAL MEDIATISATION: A \\ CONTEMPORARY REFLECTION
}

COMUNICACIÓN ORGANIZACIONAL Y MEDIATIZACIÓN SOCIAL: UNA REFLEXIÓN

CONTEMPORÁNEA

\author{
Daiana Stasiak \\ Professora da Faculdade de Informação e \\ Comunicação (FIC) da Universidade Federal de Goiás (UFG) \\ daiastasiak@gmail.com
}

\section{Resumo}

O artigo propõe a midiatização social como um suporte teórico relevante para discutir os fenômenos relacionados à interação entre organizações, meios de comunicação e sujeitos e a autonomia de cada uma dessas instâncias advinda, principalmente, a partir do desenvolvimento das tecnologias. Nesse sentido, o trabalho objetiva contribuir com as reflexões contemporâneas da comunicação organizacional que se preocupam com questões emergentes numa sociedade complexa regida por paradigmas dialógicos e relacionais.

Palavras-chave: Comunicação organizacional. Midiatização social. Meios de comunicação. Teorias.

\begin{abstract}
The article proposes the mediatisation social as a theoretical support relevant to discuss the phenomena related to the interaction between organizations, media and subjects and the autonomy of each of these originated from, mainly, from the development of Technologies. In this sense, the work aims to contribute to contemporary reflections of organizational communication that are concerned with emerging issues in a complex society governed by paradigms emancipatory and relational.
\end{abstract}

Keywords: Organizational communication. Social mediatisation. Media. Theories 


\section{Resumen}

El artículo propone una cobertura de los medios de comunicación social como un marco teórico relevante para analizar los fenómenos relacionados con la interacción entre las organizaciones, los medios de comunicación y las personas y la autonomía de cada uno de estos casos se derivan principalmente del desarrollo de las tecnologías. En este sentido, el trabajo pretende contribuir para la reflexión de la comunicación organizacional contemporánea se ocupan de cuestiones emergentes en una sociedad compleja gobernada por paradigmas dialógicos y relacional.

Palabras clave: Comunicación organizacional. La cobertura de los medios de comunicación social. Medios. Teorías.

\section{INTRODUÇÃO}

Nos estudos da comunicação organizacional encontramos pesquisadores com uma visão que consideramos inovadora sobre as perspectivas teóricas da área, pois entram em contato com conceitos que carregam em si propostas que vão além de questões lineares e transmissionistas, que, até então estavam voltadas para a funcionalidade e os resultados da organização, para lançar um olhar crítico sobre os fenômenos que surgem a partir das características da sociedade complexa. Esse olhar propõe as organizações enquanto atores sociais que demandam um comportamento aberto, construído e guiado a partir da interação com os públicos. (OLIVEIRA e PAULA, 2007; BALDISSERA, 2009; SCROFERNEKER, 2011; CURVELLO; 2009).

Os pesquisadores preocupam-se em compreender os aspectos do ambiente e em vincular a comunicação como uma estratégia contemporânea das organizações em busca de sua inserção social. Nesse sentido, trabalham com paradigmas que consideram uma perspectiva relacional e dialógica entre as organizações e seus públicos e propõem a importância de um olhar teórico mais aprofundado para legitimar a área dentro dos estudos da comunicação social.

Buscamos contribuir com essa linha de pensamento que se consolida na área inserindo nossa proposta de reflexão feita a partir do contexto do processo de midiatização social (VÉRON, 1997, FAUSTO NETO, 2006, 2008, 2010; SODRÉ, 2002). Esse olhar teórico prevê a influência mútua entre organizações, meios de comunicação e sujeitos e reflete sobre a autonomia de cada uma dessas instâncias a partir da evolução das tecnologias. Dialogamos 
com o conceito de midiatização acreditando que é um suporte coerente para discutir a condição da comunicação organizacional na atualidade.

\subsection{Definindo organizações e comunicação organizacional}

A sociedade complexa, pelas suas características, abriga um número muito grande de organizações que colaboram para a manutenção da coesão social, pois, todos os seres humanos estão imersos nelas. As demandas sociais advindas, principalmente após a Segunda Guerra, demonstram uma revolução na produtividade e a melhora das condições de produção, bem como incentivos econômicos que consolidaram muitas organizações tanto de caráter público quanto privado.

Para Margarida Kunsch (2003) o conjunto diversificado de organizações possibilita o funcionamento da sociedade, pois permite a satisfação tanto das necessidades básicas (alimentação, saúde, vestuário, transporte, segurança, habitação) quanto das sociais e culturais. Por isso, a autora entende como organizações as diversas modalidades de agrupamentos de pessoas que se associam intencionalmente para trabalhar, desempenhar funções e atingir objetivos comuns, com vista a satisfazer alguma necessidade da sociedade. Para ela, as organizações precisam se comportar como sistemas abertos, sensíveis ao ambiente externo e aos anseios da sociedade, a fim de perceber as mudanças que ocorrem na ordem social, política e econômica são fatores fundamentais para a sua subsistência.

Já Onésimo Cardoso (2006) considera simplista que alguns autores pensem uma organização apenas como um corpo humano composto por especialistas que trabalham em um conjunto de tarefas comuns. Para ele, "uma organização é mais que isso: é uma unidade coletiva de ação formada para perseguir fins específicos, dirigida por um poder que estabelece a autoridade, determina o status e o papel de seus membros" (CARDOSO, 2006, p. 1125). Ressalta ainda que as organizações são atividades reguladas por decisões baseadas em uma filosofia e também devem ser consideradas como sistemas que expressam um conjunto dentro da história social.

A união das propostas de Kunsch (2003) e Cardoso (2006) embasa nosso entendimento da organização como uma unidade coletiva formada por pessoas que trabalham a partir de uma filosofia para atingir fins específicos e para sobreviver precisa agir como sistema aberto sensível ao ambiente e às transformações em todos os âmbitos sociais.

Neste trabalho, o nosso foco está sobre a área da comunicação nas organizações. Ressaltamos que ela não pode ser dissociada de uma ideia geral de comunicação. Entendemos 
que há uma defasagem em algumas abordagens quando a comunicação é vista somente como uma ferramenta de gestão, não considerando o caráter das relações e a complexidade do movimento de produção constante dos sentidos que atravessam a permanência das organizações na sociedade. Ao mesmo tempo em que a vemos também como um conceito em expansão que está sendo construído aos poucos e vai contra a "enorme sucessão de manuais que apenas reforçam a dimensão operacional e tarefista desse fazer comunicativo" (PINTO, 2011, p. 85).

Aqui optamos pelo uso do termo comunicação organizacional, pois, é o que nos parece mais adequado ao campo “já que o sufixo al exprime a ideia de relação com o substantivo organização, que origina o adjetivo organizacional' (LIMA, 2011, p. 117). Conforme a pesquisadora mencionada a expressão imprime um significado em que a comunicação passa a ser entendida a partir da relação entre os interlocutores, não restrita a um local determinado, considerando a organização como um sujeito social complexo em interação com seus membros e a sociedade.

\subsubsection{Comunicação organizacional: uma perspectiva relacional e dialógica}

Dentre os conceitos da área da comunicação organizacional, escolhemos como um dos trabalhos do que consideramos uma nova perspectiva a obra $O$ que é Comunicação estratégica nas organizações? (2007) das autoras Ivone de Lourdes Oliveira e Maria Aparecida de Paula. Elas partem da tese defendida por Oliveira (2002) na Universidade Federal do Rio de Janeiro (UFRJ) para conceituar o que denominam como paradigma da interação comunicacional dialógica, onde a comunicação é vista como um processo plural de troca entre atores sociais, em que a própria organização é também um ator social.

A proposta envolve a gestão de relacionamentos e "enfatiza oportunidades de interação e diálogo da organização com os atores sociais, planejadas e conduzidas de forma sistematizada e monitorada" (OLIVEIRA e PAULA, 2007, p.47). Essa natureza dialógica nos interessa, pois é um dos pressupostos que nos indica que o paradigma clássico envolvendo as figuras estáticas de organização enquanto emissor ativo e público como receptor inerte não prosperam mais. Numa sociedade que se desenvolve com o progresso tecnológico o surgimento da comunicação em rede, a facilidade de troca de informações, a publicação de opiniões e a abertura de espaços de interação entre os sujeitos são fatores a serem considerados; 
Se antes se pensava na possibilidade de controlar os sentidos a partir de estratégias de comunicação, na atualidade, diante das grandes transformações, as organizações se deparam com a necessidade de considerar o imprevisto, as tensões e as rupturas nas suas estratégias (OLIVEIRA, PAULA, MARCHIORI, 2012, p.9).

Pensar a área sob o viés da dimensão estratégica pressupõe que a comunicação seja exercida como um processo através da combinação e articulação entre a publicação de informações e a construção de fluxos relacionais. Sendo que as organizações precisam compreender "a necessidade de se relacionarem de forma intencional e estruturada com a sociedade, prestar contas da sua atuação e reconhecer o papel e ação dos atores sociais. (OLIVEIRA E PAULA, 2006, p.5).

Neste sentido, o paradigma relacional parece-nos um olhar coerente com a realidade, pois considera emissor e receptor enquanto interlocutores, além de pensar na influência dos contextos econômico, político, histórico entre outros que envolvem a organização e também reconhecer o papel da mensagem e dos meios envolvidos sejam eles de grande alcance como os de comunicação ou de pequeno como as situações face a face.

As autoras defendem um modelo em que "a comunicação organizacional engloba políticas e estratégias elaboradas a partir dos valores e objetivos da organização, numa dimensão articulada à gestão, às expectativas e demandas dos atores sociais com os quais interage" (OLIVEIRA e PAULA, 2007, p. 21). A seguir apresentamos a figura que ilustra o modelo proposto por elas. 


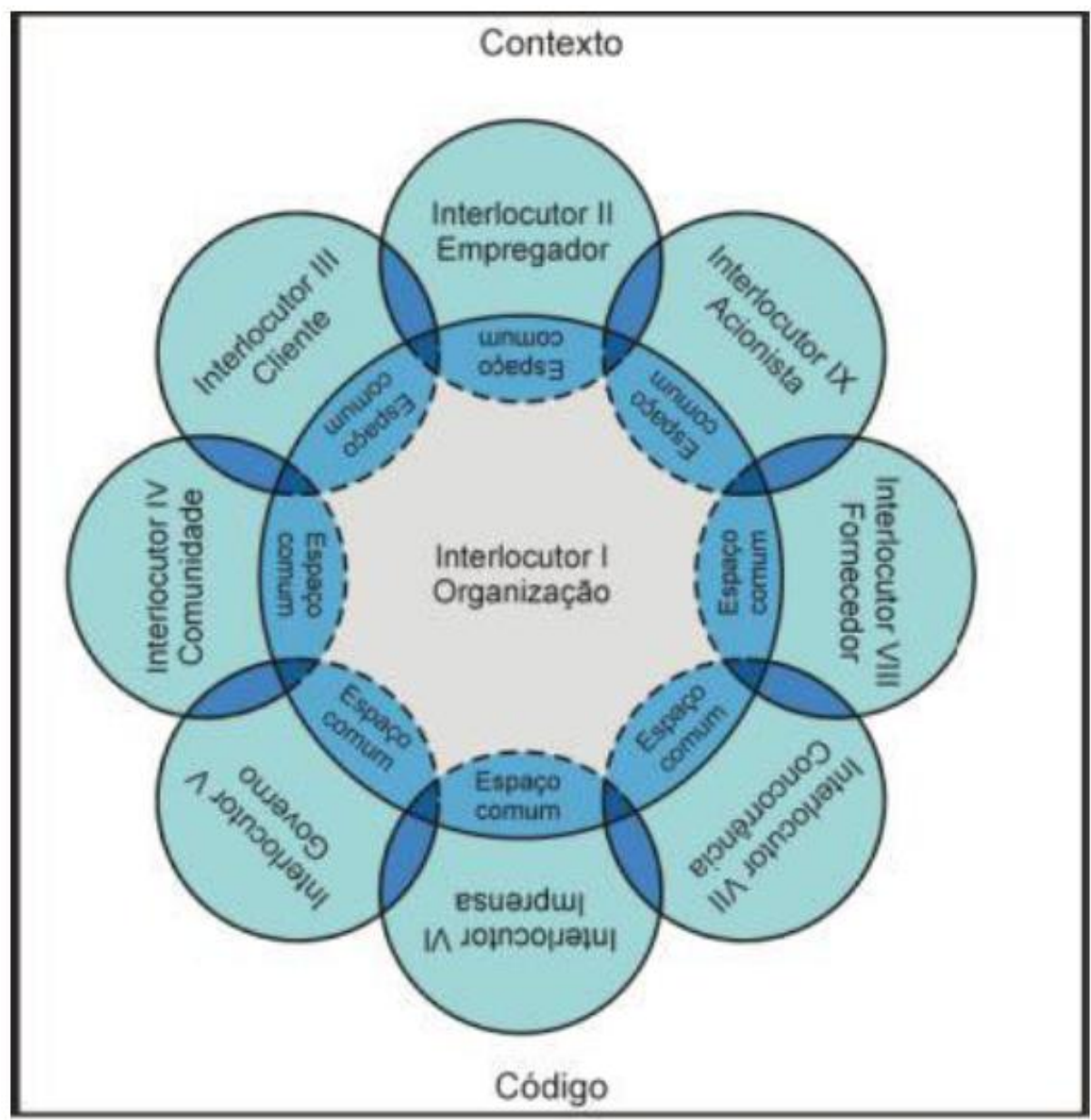

FIGURA 1: Modelo de interação comunicacional dialógica.

Fonte: Oliveira e Paula (2007, p.27)

Conforme percebemos na figura a organização é reconhecida como um dos interlocutores, o mais importante a ressaltar é que "o modelo volta-se especialmente para a autonomia do receptor, introduzindo o componente do espaço comum" (ibidem, p.27). Um ambiente no qual todos argumentam, dialogam e relacionam-se diante de um interlocutor ou de vários que compõem o circuito em que se insere a organização.

Segundo as autoras, no Brasil, "até o final da década de 1980, a área da comunicação nas organizações tinha uma atuação marcadamente tática, associada à produção de jornais internos e a ações esporádicas de comunicação externa" (ibidem, 2006, p.3). Do mesmo modo em que era estritamente dividida em ações de jornalismo, publicidade e relações públicas de modo desarticulado e sem um direcionamento que garantisse seu tratamento processual.

Mas, após essa época, com a estabilidade democrática e a ampliação dos direitos civis as organizações passaram a definir novas posturas, pautadas no planejamento e na visão estratégica da área. Para Oliveira e Paula (ibidem, p. 12) “os movimentos decorrentes das exigências da sociedade contemporânea enfatizam a importância da gestão dos 
relacionamentos da organização com os atores sociais", essas transformações solicitam novos papeis a serem desempenhados pelas organizações.

Pensamos nessa visão teórica com interesse especial, pois considera que as organizações buscam a legitimação através de negociações e compromissos com todos os grupos afetados por suas políticas e ações, essa interlocução com os demais pressupõe argumentação, troca de informações e diálogo, uma perspectiva além da linearidade e de conceitos que consideram que haja o predomínio de ideias do emissor sobre o receptor. "Nessa articulação, os interlocutores passam a ser vistos não apenas como receptores, mas como sujeitos de comunicação e agentes de interpretação, significação e ressignificação dos discursos" (OLIVEIRA, PAULA, MARCHIORI, 2012, p.8).

É interessante refletir sobre como essas negociações entre organização e seus interlocutores são realizadas através dos meios de comunicação, em especial a internet, assim corroboramos com as autoras quando expressam que "nesse espaço os atores sociais constroem discursos e buscam, através deles, legitimar sua atuação a partir da visibilidade midiática." (ibidem, p.6).

Desse modo, as organizações inserem-se, cada vez mais, na lógica midiatizada e suas ações são baseadas na busca pela visibilidade e interação através das novas tecnologias que se tornaram também eixos da construção das rotinas dos sujeitos, por isso entendemos que a perspectiva relacional e dialógica é coerente com o cotidiano de transformações na autonomia dos sujeitos em manifestar sua opinião sobre os produtos e serviços das organizações.

\subsubsection{Contra tendências da comunicação organizacional: a visão dos autores sob o olhar da complexidade}

Não podemos ignorar que as propostas atuais ainda convivem com outra parte que concebe a comunicação como uma ferramenta movida pelas demandas do cotidiano e acionadas de forma instrumental, mas ressaltamos que a ideia do nosso estudo é trabalhar com autores que busquem novos paradigmas.

Nesse contexto, destacamos Cleusa Scroferneker (2011) que realizou um estudo onde retomou diversos autores que trabalham o conceito de comunicação organizacional, no qual uniu as abordagens que denominou como contra tendências "a expressão deixa claro que esses novos olhares buscam alternativas paradigmáticas às tendências predominantes atreladas ao 
paradigma funcionalista, estabelecendo outros contornos para a comunicação organizacional" (SCROFERNEKER, 2011, p.2).

Para a referida autora as teorias contemporâneas da comunicação organizacional não excluem nem negam as abordagens existentes e sim estimulam outros movimentos e olhares que trazem novas opções para avançar e fortalecer o conhecimento. Scroferneker (2011) cita a abordagem de Oliveira e Paula (2007) sobre a perspectiva relacional que concebe a comunicação organizacional como um processo de construção conjunta entre interlocutores, a partir de discursos e do contexto. Para ela, a abordagem ocasiona um avanço significativo nos trabalhos de investigação empírica porque evidencia a comunicação como um processo multirreferencial, sempre renovado a partir de articulações entre as instâncias da emissão, circulação e recepção.

O trabalho de João Curvello (2009) também é visto como uma contra tendência na área, pois o autor realiza seus estudos sob a abordagem sistêmico-comunicacional de Niklas Luhmann onde este propõe que o pensamento complexo extrapola os limites do pensamento linear e mecanicista do mundo e parte do pressuposto de que não é possível reduzir a multidimensionalidade do ambiente organizacional que hoje sofre profundas transformações.

Juntos, Curvello e Scroferneker (2008) publicam um trabalho que traz a análise da comunicação organizacional a partir das perspectivas da autopoiese de Luhmann e da complexidade de Morin, onde destacam que os modelos de gestão marcados pelo controle e normatização que consideravam a organização como um todo e suas partes, passam a ser substituídos pelas diferenças entre sistema e entorno que estão mais centradas nos ruídos e na complexidade, advindos das relações com todos aqueles envolvidos em seus processos. "Para as organizações contemporâneas isso implica confrontar-se, no seu cotidiano, com realidades, situações e acontecimentos não mais tão previsíveis e tangíveis, ressignificando as suas ações e práticas" (CURVELLO E SCROFERNEKER, 2008, p. 7).

Consideramos que a facilidade em produzir mensagens e interagir através dos dispositivos tecnológicos da internet leva as organizações a entrarem em contato com o que os autores denominam "um enfoque mais interacional, circular e sistêmico em oposição ao pensamento simplificador, reducionista e linear" (ibidem, 2008, p. 15), essa é uma postura mais coerente com a atualidade, pois investe em pressupostos não somente de imagem e representação, mas também de construção conjunta, em busca da reputação diante dos públicos vinculados a ela.

As mudanças do ambiente inicialmente são quase imperceptíveis até irem ganhando corpo e emergirem como transformações qualitativamente diferenciadas. Neste sentido, a 
postura das organizações diante das tecnologias é um exemplo, pois sua inserção foi acontecendo de maneira lenta até se tornar algo imprescindível para sua existência.

Rudimar Baldissera (2011) enfatiza que a sociedade se constrói de forma cada vez mais complexa e precisamos compreendê-la como uma teia simbólica que é tecida pelos sujeitos através das relações. Numa perspectiva hologramática, considera que as organizações são subsistemas que fazem parte do todo social e "caracterizam-se por serem da qualidade do relacional, do interdependente e atualizarem-se em interações e inter-relações" (ibidem, p.154).

Ele propõe que a comunicação não se restringe a espaços físicos e sim a fluxos de sentidos compostos por diversas qualidades de conteúdo e forma, por isso precisa ser trabalhada a partir do respeito à diversidade e do entendimento do conflito como uma possibilidade de criação, entre as características mais relevantes do autor está a proposta do planejamento estratégico como um norteador e não como uma certeza, pois a cultura organizacional se reconstrói a partir das relações.

Quantificar os anúncios, avaliar o aumento das vendas, verificar os acessos ao site, ou valores de mídia espontânea são ações possíveis e que movimentam a organização, porém, não se pode pensar que a comunicação é reduzida somente a esses processos. "Importa observar que assim como existem intenções no pólo da produção e proposição também existem intenções nos interlocutores" (BALDISSERA, 2009, p.118).

Os autores supracitados que trabalham a comunicação organizacional a partir da perspectiva complexa, incluem conceitos que dizem respeito às transformações decorrentes também a partir das novas tecnologias, por isso sustentamos a ideia de que as organizações encontram-se diante do processo de midiatização no qual a complexidade pode ser compreendida como a qualificação do cenário diante do qual constroem suas rotinas.

Acreditamos que a escolha de Morin (2006) para embasar alguns autores da comunicação organizacional justifica-se porque ele foi um dos primeiros pensadores a refletir sobre a cultura de massa, e, com base na proposta da complexidade repensou a sociedade a partir de uma visão em que articulou diversos campos como física, biologia, psicologia, economia, arte, ciência, tecnologia e comunicação. A abordagem de Morin, feita a partir dos anos de 1960, demonstra o entendimento de como a sociedade é um sistema aberto em constante transformação. Essas mudanças culminam no século XXI em que percebemos os campos cada vez mais interconectados, principalmente por meio das tramas das novas tecnologias. 
Dessa forma os paradigmas simplificadores que reduzem a comunicação organizacional a um instrumento precisam ser reestruturados. Nesse sentido, a busca da área pela renovação vista nas falas dos autores escolhidos demonstram que estão em curso novos pensamentos que envolvem a complexificação da teia social, algo fundamental para seu firmamento enquanto uma área estratégica.

Nesse sentido, consideramos que está em vias de consolidação um movimento crítico com base nos fenômenos contemporâneos de formação de uma base teórica para a área da comunicação organizacional. Nesse olhar renovado, a interação entre a organização e todos os interlocutores ligados à sua existência é um ponto fundamental. A nossa colaboração aponta a perspectiva da midiatização social como um subsídio teórico que pode colaborar com o desenvolvimento dos estudos da área na atualidade, conforme demonstram os subtítulos a seguir.

\subsection{A proposta de esquema para análise da midiatização}

O argentino Eliseo Verón foi um dos primeiros a trabalhar com a midiatização enquanto tema de estudo, por isso é utilizado como fonte de grande parte dos pesquisadores brasileiros. Em seu texto Esquema para el análisis de la mediatización (1997) o autor postula que enquanto a comunicação midiática resulta da articulação entre dispositivos tecnológicos e condições específicas de produção e recepção, a midiatização surge como processo decorrente da acelerada evolução tecnológica, bem como das demandas sociais, as quais fazem com que o ser humano aspire novas formas de comunicação, diferentes daquelas possíveis através dos meios de massa.

Para Verón (1997) o termo midiatização foi adotado no início dos anos 1990, tanto na Europa quanto na América Latina, pelos pesquisadores que trabalhavam com as tecnologias da comunicação. Particularmente, cita uma conferência na Universidade de Paris VIII, onde se discutiu a hipótese de que as sociedades pós-industriais estariam entrando em uma nova etapa denominada por alguns como hipermediatização, sobremodernidade, multimeios, todas as denominações consideravam a hipótese da exacerbação da modernidade.

Para discutir os múltiplos aspectos que envolvem esse fenômeno o autor propõe um esquema no qual identifica fluxos que compõem a midiatização, onde são encontradas características como a complementaridade entre emissor e receptor, a horizontalidade na troca de mensagens e a presença do feedback. Ponderamos que o esquema de Verón (1997) vai 
além do sistema tradicional, pois pensa na autonomia de cada parte no processo comunicacional a partir da influência das novas tecnologias.

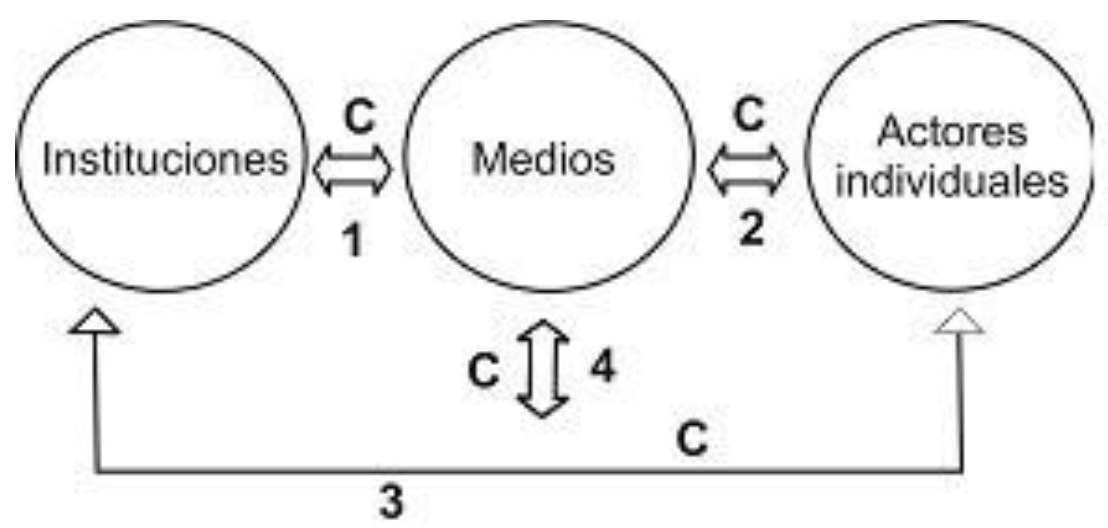

FIGURA 2: Esquema para análise da midiatização.

Fonte: Verón (1997).

No esquema ilustrado o círculo denominado "instituições" designa os múltiplos ordenamentos organizacionais da sociedade, já os meios ocupam a centralidade que se justifica pelos pressupostos da midiatização. Por fim, os atores, são designados como individuais para se excluírem as possibilidades de coletivo e caracterizá-los como sujeitos, membros inseridos em complexas relações sociais. As flechas duplas explicitam as operações através das quais se constroem os coletivos a partir da interação.

Em $\mathrm{C} 1$ temos a relação entre meios e instituições, nesse artigo em específico, Verón (1997) exemplifica o campo político como uma instituição e considera que nos países democráticos os meios de comunicação são capazes de transformar os modos de gestão dos governos. Como exemplo, o autor refere-se ao episódio em que o ministro da economia foi demitido pelo presidente argentino por meio de um programa de rádio.

Num acontecimento mais recente, ocorrido no Brasil, o prefeito de João Pessoa, demite seu secretário através do twitter, no mês de junho de 2012, podemos visualizar uma situação semelhante, porém ampliada pela própria evolução do dispositivo tecnológico, que agora é a internet. 


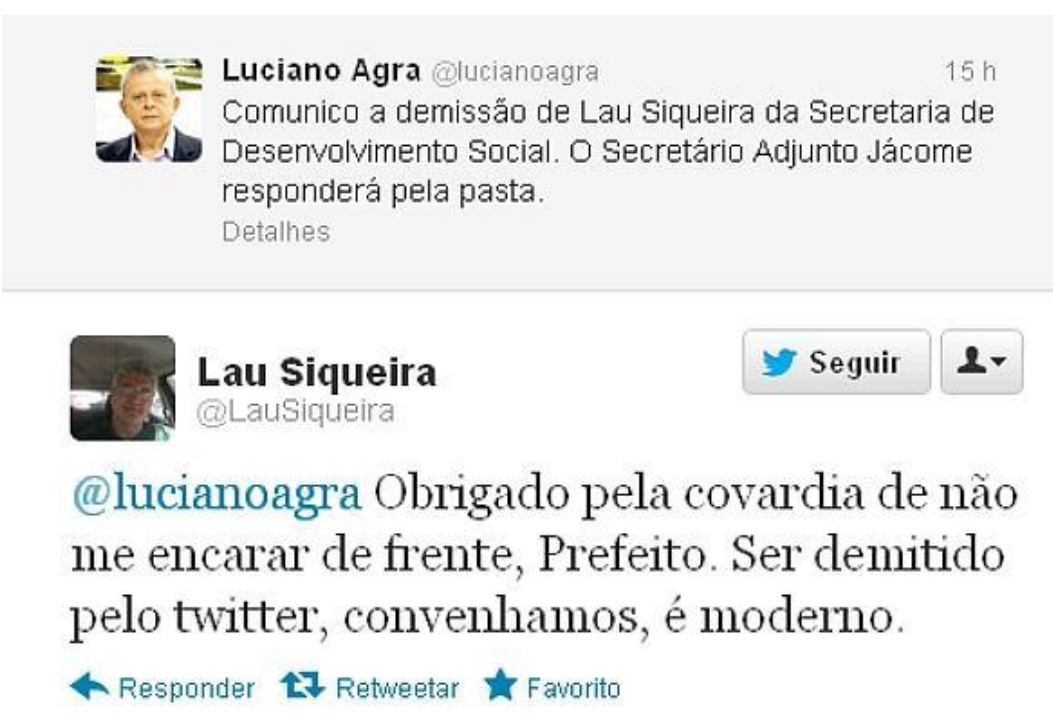

FIGURA 3: Demissão de secretário municipal de joão pessoa via twitter.

Fonte: Matéria Estadão Online ${ }^{1}$

O fato destacado designa a influência das tecnologias da comunicação sobre as rotinas das organizações, quando o prefeito utiliza uma rede social, provavelmente, tem a pretensão de dar visibilidade instantânea à sua decisão, ao mesmo tempo, torna-se vulnerável a uma resposta pública feita a partir do tipo de interação proporcionada pela mídia social, pois o secretário demitido tem no mesmo espaço a oportunidade de mencionar o nome de seu chefe e questionar sua atitude e integridade, como o faz.

Já na relação entre meios e atores individuais (C2), o autor entende que o aumento do consumo das produções midiáticas, nos últimos 30 anos, influenciou todos os âmbitos da vida dos sujeitos agindo sobre o que consideravam, por exemplo, família, corpo, sentimentos, preconceito, uso do tempo livre, entendimento sobre saúde, economia, meio ambiente, entre outros temas. Do mesmo modo, o comportamento e a preferência dos sujeitos influenciaram os assuntos veiculados e os tipos de programação que foram sendo desenvolvidas nos meios ao longo dos anos.

Ao avaliar o fluxo entre instituições e atores individuais (C3) o autor mencionado pensa sobre as mudanças que ocorreram no ambiente organizacional a partir da multiplicação de veículos de comunicação, para ele a cultura interna é transformada no momento em que colaboradores vêem circular mais informações do seu trabalho e da própria organização. Esse aspecto nos interessa porque Verón (1997) considera as instituições como ordenamentos organizacionais e reflete sobre a troca de mensagens entre elas e os sujeitos.

1 Disponível em http://blogs.estadao.com.br/radar-politico/2012/06/22/prefeito-de-joao-pessoa-demitesecretario-pelo-twitter/. Acesso em 12 mai. 2012. 
Por fim, a flecha em C4 significa a influência das regras midiatizadas sobre os processos de comunicação tanto das instituições quanto dos sujeitos. O exemplo utilizado por Verón para descrever esse fluxo é o de um colaborador que tem contato com um escândalo sobre sua empresa através dos meios de comunicação e as consequências que esse fato teria sobre sua relação e identificação com ela. À época (1997) esse exemplo até poderia ser válido como um processo de influência da lógica dos meios sobre as demais instâncias, mas, na configuração atual, torna-se interessante pensarmos esse fluxo a partir do desenvolvimento da internet que oferece as possibilidades tecnológicas para que sujeitos e organizações ajam segundo lógicas semelhantes aos meios de comunicação.

Hoje, por exemplo, esse mesmo colaborador poderia ter acesso não somente às informações sobre sua empresa publicadas em jornais, mas também ver opiniões dos sujeitos que expressam seus sentimentos e preferências, elogiam ou reclamam sobre os acontecimentos. Recentemente vimos casos como o da marca $\mathrm{Arezzo}^{2}$ com o uso de peles em sua coleção e também do Greenpeace ${ }^{3}$ contra a Nestlé pelo trabalho com fornecedores que desmatam florestas para a produção de óleo de dendê utilizado na fabricação de produtos da multinacional. Esses acontecimentos demonstram mudanças no sentido da autonomia em publicizar algo e tornar essas informações referências sem passar, necessariamente pelos meios de comunicação tradicionais.

Consideramos o esquema de Verón (1997) como o princípio de algo diferente daquilo que encontramos nos conceitos tradicionais onde as lógicas de comunicação e os fluxos estabelecidos entre organizações meios de comunicação e públicos são contemplados a partir de uma proposta não linear que aponta para as possibilidades de influência e interação entre todas as instâncias no processo de comunicação. A seguir trabalhamos com autores brasileiros que desenvolvem o conceito da midiatização a partir da realidade do nosso país.

\subsubsection{O processo de midiatização social no Brasil: um conceito contemporâneo}

Antônio Fausto Neto (2006; 2008; 2010) e Muniz Sodré (2002; 2006) estão entre os pioneiros da construção de um conceito de midiatização social no campo da comunicação do Brasil. Em suas abordagens encontramos a preocupação em ampliar o entendimento da comunicação para algo além dos efeitos dos meios, na busca pela compreensão de uma

\footnotetext{
${ }^{2}$ www.economia.ig.com.br/empresas/comercioservicos/arezzo+recolhe+pecas+com+pele+de+animais+apos+pol emica+no+twitter/n1300082648150.html Acesso em: 25 nov. 2012.

${ }^{3}$ www.greenpeace.org/brasil/pt/Noticias/Nestle-financia-destruicao-de-floresta-e-poe-orangotangos-no-rumo-daextincao/ Acesso em: 25 nov. 2012.
} 
perspectiva sociotécnica ${ }^{4}$, assim o primeiro autor nos traz ideias sobre o que denomina como a passagem de uma sociedade dos meios para uma sociedade em vias de midiatização enquanto o segundo caracteriza o bios midiático como um quarto âmbito existencial vindo com o avanço tecnológico.

Para Fausto Neto $(2006 ; 2008 ; 2010)$, a constituição e o funcionamento das práticas e lógicas da sociedade estão atravessados e permeados por pressupostos do que se denomina a cultura da mídia. A convergência tecnológica torna as fronteiras entre os campos permeáveis de modo que as lógicas midiáticas expandem-se para as práticas sociais de todos os campos que se apropriam cada um à sua maneira, das estratégias antes restritas aos meios de comunicação.

O autor sugere que "não se trata mais da existência do campo midiático como um lugar protagonista, mas a expansão para toda a esfera da organização social de referências da cultura das mídias, como operações tecnossimbólicas" (FAUSTO NETO, 2010, p.115). Essas características são encontradas nas práticas discursivas dos demais campos como: política, religião, educação, saúde, justiça, economia entre outros, que se moldam a partir de estratégias midiáticas e redesenham a maneira pela qual buscam o reconhecimento na esfera pública.

Está em curso a transformação da "sociedade dos meios" para a "sociedade em vias de midiatização" com novas estruturas e relações dinâmicas entre produtores e receptores de discursos, uma das principais características é o receptor ser re-situado em outros papeis na própria arquitetura comunicacional emergente, que ocasiona uma mudança de sentido das funções de cada parte no processo (FAUSTO NETO, 2008)

Já o pesquisador Muniz Sodré em sua obra Antropológica do Espelho: uma teoria da comunicação linear e em rede, publicada em 2002, aborda a experiência do advento das novas tecnologias e coloca em discussão questões sobre a transformação de interesses e costumes, novas referências simbólicas em educação e política, transformação dos processos de construção da realidade e normas e valores de sociabilidade. Em sua essência propõe que a obra sugere pensar "uma antropologia ético-política da comunicação, o que equivale a dizer, uma teoria do processo constitutivo do bios midiático ou realidade virtual e seu relacionamento com as formas de vinculação social” (SODRÉ, 2002, p. 221).

\footnotetext{
${ }^{4}$ Para os autores que trabalham com o conceito de midiatização a sociedade e a tecnologia não podem ser dissociadas.
} 
A ideia de bios virtual é apresentada como um quarto âmbito existencial, onde existe uma tendência à virtualização ou telerrealização das relações humanas. Nele se configura um novo modo de vida, que coloca o indivíduo diante de outras formas de sociabilidade realizadas, principalmente, através da tecno-interação, ou seja, a interação através de meios técnicos. A globalização é o pano de fundo, que denomina como um sinônimo para a "teledistribuição mundial de pessoas e coisas" (ibidem, p.12). Considera que esse fato é um pressuposto para compreender a passagem da comunicação de massa (centralizada, vertical e unidirecional) à dimensão tecnológica do virtual.

O autor aponta um novo regime de visibilidade pública, onde as pessoas vivem fragmentadas e dispersas em termos de contatos humanos e políticos, porém se encontram sistematicamente conectadas. Essa proposta nos ajuda a pensar no modo como as estratégias podem ser dirigidas na atualidade, onde a presença física não é determinante para a existência da interação, conforme foi, por muitos anos.

$\mathrm{O}$ autor acredita que as características da midiatização precisam fazer com que o saber comunicacional reescreva a realidade tradicional pelo viés das novas tecnologias de modo a repensar o relacionamento dos sujeitos através do mundo virtual para compreender criticamente o sentido ético-político de seus modos de presença na sociedade. Desse modo, o campo precisa compreender como essas transformações atuam em termos de influência na construção da realidade social desde o primeiro jornal impresso até as redes sociais.

Para Sodré (2002, p.23), “a maior parte das pesquisas até agora realizadas, tem levado à convicção de que a mídia é estruturadora ou reestruturadora de percepções e cognições, funcionando como uma espécie de agenda coletiva". As tecnologias trazem novos sentidos para o campo da comunicação, onde as mudanças individuais em aspectos como a sociabilidade e a interação, realizadas pela grande maioria da população caracterizam um comportamento coletivo que precisa ser entendido em sua essência, pois está diretamente relacionado ao nosso campo de estudo.

\subsection{A comunicação organizacional sob a perspectiva da midiatização: novos paradigmas para a reflexão}

Neste trabalho defendemos que as ideias chave presentes no conceito de midiatização social podem ser imbricadas às teorias da comunicação organizacional, pois, características apontadas nesse conceito, como por exemplo, a complementaridade entre as ações do emissor e do receptor, a horizontalidade na troca de mensagens e a presença constante do feedback 
demonstram processos que estão em curso a partir do desenvolvimento das tecnologias e podem ser levados em conta nas abordagens teóricas da comunicação organizacional para que sejam mais coerentes com a realidade.

Conforme vimos, o conceito reflete sobre a comunicação na contemporaneidade e entende que as tecnologias de informação e comunicação (TICs) constroem um novo ambiente no qual meios, sujeitos e organizações influenciam-se mutuamente, uma concepção que vai em direção à quebra de sentido da fórmula linear Emissor-Canal-Receptor (E - C - R) característica única, por muitos anos, também nos estudos da comunicação organizacional.

No âmbito da lógica midiatizada as organizações estão inseridas em um ambiente complexo que demanda uma gestão estratégica. Nesse sentido, Cardoso (2006) ressalta que a informação e os processos de comunicação sempre estiveram presentes nas ações que buscam a evolução da organização, e, na atualidade ocupam um papel relevante para ampliar e integrar as estruturas e garantir a manutenção de suas ações bem como da própria existência. Ele considera que as organizações são o resultado de um processo dialógico com o meio ambiente e, por isso, a área da comunicação necessita desprender-se de alguns padrões tradicionais e ser incorporada por todos os setores com o objetivo de construir uma gestão estratégica.

Quando Verón (1997) indica que o cotidiano está sendo moldado pelas tecnologias onde as regras midiatizadas influenciam nos processos de comunicação tanto das instituições quanto dos sujeitos, percebemos que a simples possibilidade de um consumidor reclamar de uma organização através das redes sociais interfere diretamente na postura que ela irá adotar para resolver esse problema ${ }^{5}$. Entendemos que isso já faz parte da esfera pública, onde acontecimentos como esses são indicadores de que as rotinas e experiências das organizações estão sofrendo transformações.

Aqui visualizamos uma proposta diferente da que encontramos na estrutura tradicional, pois a relação não é apenas linear e vertical, uma vez que também pode se iniciar pelo sujeito, antes configurado apenas como receptor, hoje o consumidor utiliza o meio para dar visibilidade à sua opinião. O feedback da organização indica que se estabeleceu um diálogo e todo o processo encontra-se sob as novas possibilidade de visibilidade estratégica, tanto do sujeito, que entende que publicizar o fato vai lhe beneficiar, quanto da organização

\footnotetext{
5 Esta reportagem é um bom exemplo da mudança de postura das organizações na atualidade. http://www1.folha.uol.com.br/tec/989698-redes-sociais-sao-mais-ageis-que-sac-como-canal-dereclamacao.shtml Acesso em 10 mai. 2012.
} 
que precisa estar no meio para manter sua imagem e reputação nessa esfera pública de novas possibilidades.

Oliveira (2009) traz uma consideração adequada a esse contexto quando propõe que a economia globalizada exige que as organizações revejam sua postura diante da sociedade. Por isso elas passam a incorporar discursos que valorizam práticas responsáveis e a criação do capital social, ampliando sua capacidade interativa em busca da reputação considerada um diferencial, "pois a credibilidade e a respeitabilidade conquistadas determinam se a organização permanecerá ou não na sociedade e estabelecem sua legitimidade pública" (OLIVEIRA, 2009, p.7)

Essa concepção pode ser vinculada à ideia de Sodré (2002), quando defende que na esfera midiatizada não basta a visibilidade pura e simples das organizações na mídia através da excessiva exposição de sua imagem na tevê ou nos jornais. É preciso que se apele para todo um arsenal de identificações entre a imagem e audiência a fim de se obter efeitos, não mais apenas projetivos, e sim de reconhecimento narcísico de si mesmo no espelho tecnocultural.

\section{CONSIDERAÇÕES}

Os autores mencionados ao longo do texto refletem sobre o conceito de midiatização social enquanto um fenômeno que gera mudanças em toda a sociedade. Nesse contexto, entendemos que as organizações sofrem de maneira mais intensa essas transformações, justamente pelo seu papel de interação constante com os indivíduos. Nesse sentido, os conceitos da área da comunicação organizacional trazidos para a discussão possuem uma visão pertinente à realidade em que nos encontramos porque consideram uma perspectiva dialógica e relacional que compreende o cenário de complexidade no qual as organizações estão inseridas.

Corroboramos com Eugenia Barichello (2008) quando aponta que um novo conhecimento deve substituir o anterior no qual as organizações realizavam a comunicação com base em postulado de linearidade, sem levar em conta os sujeitos e pressupunham que as mensagens seriam consumidas de modo quase automático, sem considerar a instância interpretativa da recepção.

Na sociedade de ambiência midiatizada a proposta da instituição pode ser modificada pelos sujeitos. A emergência de novos espaços de interação, 
especialmente na internet, amplia as possibilidades de resposta e a interpretação desses sujeitos que possuem condições de construir seus próprios espaços de atuação e, dessa forma, colocar em debate questões de seu interesse (BARICHELLO, 2008, p. 244).

Procuramos aqui a construção de uma visão estratégica que justifique a inserção das organizações na sociedade complexa em que atuam. Dessa forma, acreditamos que refletir sobre a perspectiva da midiatização junto aos estudos da área da comunicação organizacional colabora para o que denominamos como um paradigma contemporâneo que contribui para o entendimento de fenômenos baseados na interação entre sujeitos e organizações e, principalmente na descentralização e autonomia para a publicação e visibilidade de informações e opiniões através do meios de comunicação.

\section{REFERÊNCIAS}

BALDISSERA, R. Comunicação Organizacional na perspectiva da complexidade. ORGANICOM. Revista Brasileira de Comunicação organizacional e Relações Públicas. Ano 6. Edição especial. Números 10 e 11, 2009.

Comunicação organizacional: uma reflexão possível com base no paradigma da complexidade. In: OLIVEIRA, I, L; SOARES, A, T, N. Interfaces e tendências da comunicação no contexto das organizações. 2 ed. São Caetano do Sul, SP: Difusão Editora; Rio de Janeiro: Editora Senac Rio, 2011.

BARICHELLO, E.M.M.R. Apontamentos em torno da visibilidade e da lógica de legitimação das instituições na sociedade midiatizada. In: DUARTE, Elizabeth Bastos e CASTRO, Maria Lilia Dias. (Orgs) Em torno das mídias: práticas e ambiências. Porto Alegre: Sulina, 2008.

CARDOSO, Onésimo de Oliveira. Comunicação empresarial versus comunicação organizacional: novos desafios teóricos. Revista Administração Pública [online]. 2006, vol.40, n.6, pp. 1123-1144. I Disponível em http://www.scielo.br/pdf/rap/v40n6/10.pdf. Acesso em 15 out 2012.

CURVELLO João José Azevedo; SCROFERNEKER, Cleusa Maria Andrade. A comunicação e as organizações como sistemas complexos: uma análise a partir das perspectivas de Niklas Luhmann e Edgar Morin. E-compós. Revista da Associação Nacional dos Programas de Pós-Graduação em Comunicação. Brasília, v.11, n.3, set./dez. 2008 .

CURVELLO João José Azevedo. Os estudos de Comunicação Organizacional e as novas abordagens sistêmicas. XXXII Congresso Brasileiro de Ciências da Comunicação. Anais... Curitiba, PR, 2009. Disponível em: 
http://www.intercom.org.br/papers/nacionais/2009/resumos/R4-2746-1.pdf. Acesso em 10 set 2012.

ESTADÃO. Prefeito de João Pessoa demite secretário pelo Twitter. Disponível em: http://blogs.estadao.com.br/radar-politico/2012/06/22/prefeito-de-joao-pessoa-demitesecretario-pelo-twitter/. Acesso em 12 mai 2012.

FAUSTO NETO, Antonio. Midiatização, prática social-prática de sentido. Seminário sobre midiatização, Rede Prosul, Anais... São Leopoldo: UNISINOS, 2006. 34, 2007.

Enunciação, auto-referencialidade e incompletude. Revista Famecos. Porto Alegre, $\mathrm{n}^{\mathrm{o}}$ ㄱ. Fragmentos de uma «analítica» da midiatização. Revista MATRIZes n. 2. abril,

As bordas da circulação. Revista Alceu. V.10. N 20. Jan/jun 2010.

KUNSCH, M.K. Planejamento de Relações Públicas na comunicação integrada. $17^{\mathrm{a}}$ Ed. Summus Editorial, 2003.

OLIVEIRA, Ivone. Espaços dialógicos e relacionais nas organizações e sua natureza ético-política. IX Congreso latinoamericano de investigación de la comunicación. Estado de México, 2008. Anais... Disponível em:

http://alaic.net/alaic30/ponencias/cartas/com_org_yRP/ ponencias/GT2_16Oliveira.pdf. Acesso 18/01/2012.

OLIVEIRA, Ivone de Lourdes; PAULA, Maria Aparecida de. O que é comunicação estratégica nas organizações?. São Paulo: Paulus, 2007.

OLIVEIRAI, L,; M, A, PAULA; MARCHIORI, M. Um giro na concepção de estratégias comunicacionais: dimensão relacional. Encontro do Fórum Iberoamericano de Estratégias de Comunicação. Anais... República Dominicana, 2012. Disponível em http://www.uel.br/grupo-estudo/gecorp/images/fisec_2012_painel_texto_final_130712.pdf. Acesso em 12 nov 2012.

PINTO, J. Comunicação organizacional ou comunicação no contexto das organizações? In: OLIVEIRA, I, L; SOARES, A, T, N. Interfaces e tendências da comunicação no contexto das organizações. 2 ed. São Caetano do Sul, SP: Difusão Editora; Rio de Janeiro: Editora Senac Rio, 2011.

SODRÉ, Muniz. Antropológica do Espelho. Por uma teoria da comunicação linear e em rede. Petrópolis, RJ: Vozes, 2002.

SCROFERNEKER, C. M. A. Contra tendências paradigmáticas da Comunicação Organizacional Contemporênea no Brasil. XX Encontro da Compós, Anais... Porto Alegre, Rio Grande do Sul, 2011.

VERÓN, Eliseo. Esquema para el análisis de la mediatización. In: Diálogos de la Comunicación. Lima: Felafacs, 1997. 
Original recebido em: 29/09/2013

Aceito para publicação em: Novembro de 2013

Daiana Stasiak

Professora da Faculdade de Informação e Comunicação (FIC) da Universidade Federal de Goiás (UFG). Relações Públicas e Mestre em Comunicação Midiática (UFSM); Doutoranda em Comunicação da Universidade de Brasília (UNB). 